Article

\author{
BANARAS, S. ${ }^{1}$ (D) \\ JAVAID, A. ${ }^{1 * \mathbb{D}}$ \\ SHOAIB, A. ${ }^{1}$ (D)
}

\section{Non-Chemical Control of Charcoal Rot of URdBean BY Sonchus oleraceous APPLICATION}

\author{
Controle Não Químico da Podridão de Carvão em Feijão-Preto Utilizando \\ Sonchus oleraceous
}

\begin{abstract}
Urdbean [Vigna mungo (L.) Hepper] is an important leguminous crop whose production is severely affected by charcoal rot disease caused by Macrophomina phaseolina. This study was undertaken to seek an environmental friendly alternative to synthetic fungicides for management of this disease. Dry biomass of an allelopathic weed Sonchus oleraceous L. was used to combat the menace. Fumigated sandy loam pot soil, pre-inoculated with M. phaseolina, was amended with different doses of dry biomass of the weed ranging from $0.5 \%$ to $3 \%$. Application of $2 \%$ weed biomass completely controlled the disease. Soil inoculation with M. phaseolina inoculation (positive control) reduced shoot dry weight and grain yield of urdbean by $59 \%$ and $91 \%$, respectively, over negative control. Application of different doses of soil amendment in pathogen inoculated soil enhanced shoot dry weight and grain yield of urdbean by $107-307 \%$ and $438-7400 \%$, respectively, over positive control. The highest positive effect on growth and yield of uedbean in M. phaseolina contaminated soil was recorded due to $2.5 \%$ amendment. M. phaseolina inoculation significantly enhanced peroxidase (POX) and phenyl alanine ammonia lyase (PAL) activities. However, application of different doses of S. oleraceous biomass to the soil gradually decreased activities of these enzymes. The present study concludes that application of $2.5 \%$ dry biomass of S. oleraceous can completely control charcoal rot of urdbean and significantly enhance crop growth and yield.
\end{abstract}

Keywords: charcoal rot, Macrophomina phaseolina, non-chemical disease management, sow thistle, Vigna mungo.

RESUMO - O feijão-preto [Vigna mungo (L.) Hepper] é uma importante cultura leguminosa cuja produção é severamente afetada pela podridão do carvão causada por Macrophomina phaseolina. Este estudo objetivou buscar uma alternativa ambientalmente acessivvel aos fungicidas sintéticos para o manejo dessa doença. A biomassa seca de uma planta alelopática (Sonchus oleraceous L.) foi usada para combater a ameaça. Solo de barro fumigado, pré-inoculado com M. phaseolina, foi alterado com diferentes doses de biomassa seca da planta daninha, que variaram de 0,5\% a 3\%. A aplicação de 2\% de biomassa de plantas daninhas controlou completamente a doença. A inoculação do solo com M. phaseolina (controle positivo) reduziu o peso seco da parte aérea e o rendimento de grãos de feijãopreto em $59 \%$ e $91 \%$, respectivamente, sobre o controle negativo. A aplicação de diferentes doses de alteração do solo no solo inoculado por patógenos aumentou o peso seco da parte aérea e o rendimento de grãos de feijão-preto em 107-307\% e 438-7.400\%, respectivamente, sobre controle positivo. O maior efeito positivo no crescimento e produtividade de feijão-preto no solo contaminado por M. phaseolina foi registrado devido a uma alteração de 2,5\%. A inoculação com M. phaseolina aumentou significativamente as atividades de peroxidase (POX) $e$

${ }^{1}$ Institute of Agricultural Sciences, University of the Punjab, Lahore, Pakistan. 
fenilalanina amônia liase (PAL). Entretanto, a aplicação de diferentes doses de biomassa de $\boldsymbol{S}$. oleraceous ao solo diminuiu gradualmente a atividade dessas enzimas. O presente estudo concluiu que a aplicação de 2,5\% de biomassa seca de $\mathbf{S}$. oleraceous pode controlar completamente a podridão de carvão em feijão-preto e aumentar significativamente o crescimento e o rendimento da cultura.

Palavras-chave: podridão de carvão, Macrophomina phaseolina, manejo de doenças não químicas, serralha, Vigna mungo.

\section{INTRODUCTION}

Urdbean is a pulse crop of tropics and sub-tropics areas of the world. It is cultivated in various Asian countries such as Pakistan, India, Thailand, some African countries, and Australia (Dey et al., 2017; Vishalakshi et al., 2017). It is the third important pulse of Pakistan after chickpea and mungbean. It was cultivated on area of 15200 ha in 2017-18 with a total production of 7500 ton. It is about $5 \%$ of total pulse production of Pakistan (Anonymous, 2018). It is a multipurpose crop. Being rich in protein (20-26\%) with essential amino acids, starch (35\%), vitamins, crude fiber (5-6\%) and minerals, it is used as food for human consumption (Rajaguru and Ravindran, 1985; Shafique et al., 2011). Besides, activity of symbiotic nitrogen fixing rhizobia present in root nodules of urdbean result in enhancing soil fertility (Christopher et al., 2018). Moreover, after harvesting the pods, the residues of this crop are incorporated into the soil to enrich the soil organic matter and fertility (Vyas et al., 2018).

M. phaseolina causes charcoal rot disease in urdbean causing significant yield losses of the crop (Iqbal et al., 2003). The fungus is also reported to cause diseases in hundreds of other plant species (Kaur et al., 2012). The fungus infects roots and stems of young plants and produces many sclerotia. The pathogen is difficult to control because of high survivability potential of sclerotia (Baird et al., 2003). An effective and economically feasible control measure strategy for charcoal rot under field conditions is not available. Although some fungicides such as potassium $\mathrm{N}$-methyldithiocarbamate, dimethyl disulfide and sodium methyldithiocarbamate are effective in reducing soil inoculum of $M$. phaseolina (Chamorro et al., 2016), however, yet there is not any recommended fungicide for control of this soil-borne pathogen (Lorenzetti et al., 2017). There are some recent reports of successful in vitro management of $M$. phaseolina by extracts of various plant species namely Calotropis procera, Chenopodium album, Chenopodium murale, Imperata cylindrica and Senna occidentalis (Javaid and Amin, 2009; Waheed et al., 2016; Javaid et al., 2015; 2017a). Likewise, soil amendment with residues of Datura metel, Sisymbrium irio and Azadaricta indica successfully managed the charcoal rot of mungbean and cowpea (Javaid and Saddique, 2011; Javaid et al., 2017b; Munir et al., 2018). Methanolic extracts of some asteraceous weeds such as Cirsium arvense and Eclipta alba are known to control growth of $M$. phaseolina in vitro (Banaras et al., 2017). It was hypothesized that use of dry biomass of asteraceous weeds as soil amendment can management diseases by $M$. phaseolina in vivo also. Keeping in view this hypothesis, the present study was conducted to evaluate the possible role of S. oleraceous dry biomass as soil amendment for management of charcoal rot disease in urdbean.

\section{MATERIALS AND METHODS}

\section{Preparation of inoculum}

After thorough washing with tap water, $1 \mathrm{~kg}$ pearl millet seeds were lightly boiled to make them soften. Thereafter, these seeds were packed in polythene bag and autoclaved at $121{ }^{\circ} \mathrm{C}$ for half an hour. After cooling, autoclaved seeds were inoculated with freshly prepared and actively growing culture of $M$. phaseolina. The fungal pathogen was previously isolated from a charcoal infected plant of urdbean.

\section{Soil sterilization}

Soil of sandy loam texture with $0.86 \%$ organic matter, $95 \mathrm{mg} \mathrm{kg}^{-1}$ potassium, $5.7 \mathrm{mg} \mathrm{kg}^{-1}$ phosphorus and $7.7 \mathrm{pH}$ was fumigated with formalin for 7 days. Cotton plugs soaked in formalin 
were buried in the heap of soil at different places. Soil heaps were covered with plastic sheets and left for one week. Thereafter, cotton plugs were removed, soil was thoroughly mixed and left for 5 days to completely evaporate the traces of formalin.

\section{Preparation of pots}

Experiment was conducted in earthen pots. Each pot contained $5 \mathrm{~kg}$ fumigated soil. M. phaseolina inoculum was mixed in the soil. Each pot received $50 \mathrm{~g}$ of the fungal inoculum except pots of negative control treatment where same amount of autoclaved pearl millet seeds was added. After thorough mixing of inoculum, pots were irrigated and left for one week. After that, thoroughly crushed dry biomass of the selected weed species S. oleraceous was mixed in the soil of respective pots. All pots received weed biomass except pots of negative and positive control treatments. There were different doses of the weed dry biomass ranging from 0.5 to $3.0 \%$. Pots were again irrigated with tap water and left for one week to start decomposition of weed material, leaching of allelochemicals and interaction with the pathogen. Thereafter, seeds of urdbean var. Mash-97 were sown in the pots. Prior to sowing, seeds were surface sterilized with sodium hypochlorite solution (1\%) for 3 minutes and soaked in sterilized water to accelerate germination process. Initially, 20 seeds per pot were sown which were thinned to 10 uniform seedlings per pot one after germination.

\section{Treatments}

Experiment was conducted in a completely randomized design with five replicates using the following 8 treatments:

$\mathbf{T}_{\mathbf{1}}$ : control (No pathogen or weed biomass)

$\mathbf{T}_{\mathbf{2}}+$ control: Inoculation of $M$. phaseolina alone

$\mathbf{T}_{3}:$ M. phaseolina $+0.5 \%$ dry biomass of $S$. oleraceous

$\mathbf{T}_{\mathbf{4}}$ : M. phaseolina $+1.0 \%$ dry biomass of $S$. oleraceous

$\mathbf{T}_{\mathbf{5}}:$ M. phaseolina $+1.5 \%$ dry biomass of $S$. oleraceous

$\mathbf{T}_{\mathbf{6}}$ : M. phaseolina $+2.0 \%$ dry biomass of $S$. oleraceous

$\mathbf{T}_{\mathbf{7}}$ : M. phaseolina $+2.5 \%$ dry biomass of $S$. oleraceous

$\mathbf{T}_{\mathbf{8}}$ : M. phaseolina $+3.0 \%$ dry biomass of $S$. oleraceous

\section{Data collection and statistical analysis}

After 80 days of sowing, pot grown urdbean plants were harvested. Plants were uprooted and roots were carefully separated from soil, washed and dried at $60{ }^{\circ} \mathrm{C}$ for determination of dry weight. Pods were separated from shoots. There length, number of pod per pot and pod dry weight were measured. Likewise, shoot dry weight, number of seeds per pod, grain yield, 100 grain weight and harvest index were recorded. POX and PAL activities were done by methods given by Kumar and Khan (1982) and Dickerson et al. (1984).

All the data were subjected to ANOVA followed by mean separation by Tukey's HSD Test at $\mathrm{P}=0.05$ using software Statistix 8.1.

\section{RESULTS AND DISCUSSION}

\section{Effect of soil amendment on disease incidence}

M. phaseolina inoculation without any soil amendment in positive control caused charcoal rot disease in all the plants showing 100\% disease incidence. Application of dry material of $S$. oleraceous significantly reduced disease incidence to variable extents depending upon dose of 
soil amendment. A complete eradication of disease with $0 \%$ incidence was recorded in $2.0 \%$ and higher doses of soil amendment (Figure 1). Our findings are in agreement with others where appreciable inhibition of fungal growth was reported by incorporation of plant biomass of asteraceous members (Nino et al., 2006; Mouokeu et al., 2014). The low disease incidence or complete control of disease in higher doses of $S$. oleraceous could be attributed to the presence of compounds such as alkaloids, flavonoides, tannins and terpenes in S. oleraceous (Singh, 2010), which when released into the soil, reduced growth and development of M. phaseolina. Ethanolic extracts of this weed are known to inhibit the growth of a number of fungal species including Aspergillus niger (Al-Hussaini and Mahasneh, 2011). Likewise, aqueous extract of this weed showed antifungal activity against Rhizoctonia solani (Qasem and Aau Blan, 1996). S. oleraceous is rich in phenolic acids (Cambie and Ferguson, 2003), which could be the cause of antifungal activity of this weed (Carvalho et al., 2018). The phenomenon of disease suppression has been commonly related to modification to the soil caused by the organic amendment, including physicochemical properties, microbial populations, and associated processes (Bonanomi et al., 2010).
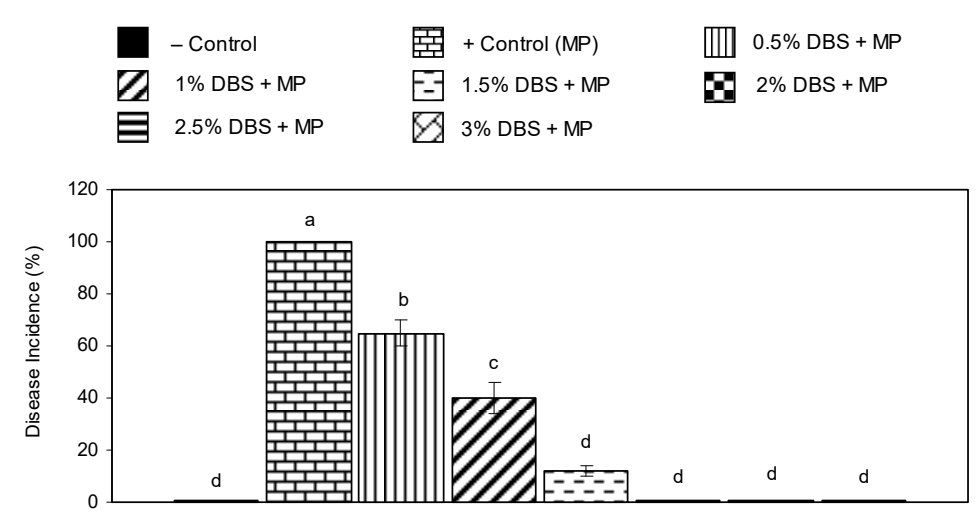

Vertical bars show standard errors of means of three replicates. Values with different letters at their top show significant difference (P $\leq 0.05)$ as determined by Tukey's HSD Test.

Figure 1 - Effect of Macrophomina phaseolina (MP) and soil amendment with dry biomass of Sonchus oleraceous (DBS) on disease incidence in urdbean.

\section{Effect of soil amendment on crop growth}

As compared to negative control, M. phaseolina inoculation in positive control reduced shoot length by $39 \%$ and shoot dry weight by $59 \%$. These shoot growth parameters showed a positive response to $S$. oleraceous dry biomass application as soil amendment resulting in significant increase over positive control treatment. In general, a gradual increase in shoot length and biomass of urdbean was recorded by increasing quantity of S. oleraceous biomass from $0.5 \%$ to $2.5 \%$ and a decline thereafter. The highest shoot length $(50 \mathrm{~cm})$ was recorded in $2.5 \%$ dose that was significantly higher than shoot length in negative and positive control treatments by $92 \%$ and $212 \%$, respectively (Figure 2A). Likewise, the maximum shoot dry weight (11.4 g) was recorded in $2.5 \%$ dose that was $68 \%$ and $307 \%$ greater than that of negative and positive control, respectively. A 3\% soil amendment had a negative effect on shoot growth of urdbean (Figure 2B).

Root length and dry biomass were $\mathrm{cm}$ and $\mathrm{g}$ in negative control, which were reduced by $64 \%$ and $61 \%$, respectively, due to $M$. phaseolina inoculation in positive control. Similar to that of shoot length, a dose of $2.5 \%$ amendment of $S$. oleraceous resulted in the maximum root length $(51 \mathrm{~cm})$ that was $101 \%$ and $467 \%$ higher than root length in negative and positive control, respectively (Figure 3A). Dry weight of root was also enhanced significantly due to application of dry material of $S$. oleraceous in the soil. The highest biomass of urdbean roots was $4 \mathrm{~g}$ per pot that was recorded in $2.5 \%$ dose and was $72 \%$ and $332 \%$ higher than root biomass in negative and positive control, respectively. Application of $3 \%$ dose negatively affected root growth (Figure 3B). 


\begin{tabular}{|c|c|c|}
\hline - Control & 四 + Control (MP) & ||⿴囗十 $0.5 \% \mathrm{DBS}+\mathrm{MP}$ \\
\hline $1 \% \mathrm{DBS}+\mathrm{MP}$ & $1.5 \% \mathrm{DBS}+\mathrm{MP}$ & $2 \% \mathrm{DBS}+\mathrm{MP}$ \\
\hline 国 $2.5 \% \mathrm{DBS}+\mathrm{MP}$ & $3 \% \mathrm{DBS}+\mathrm{MP}$ & \\
\hline
\end{tabular}
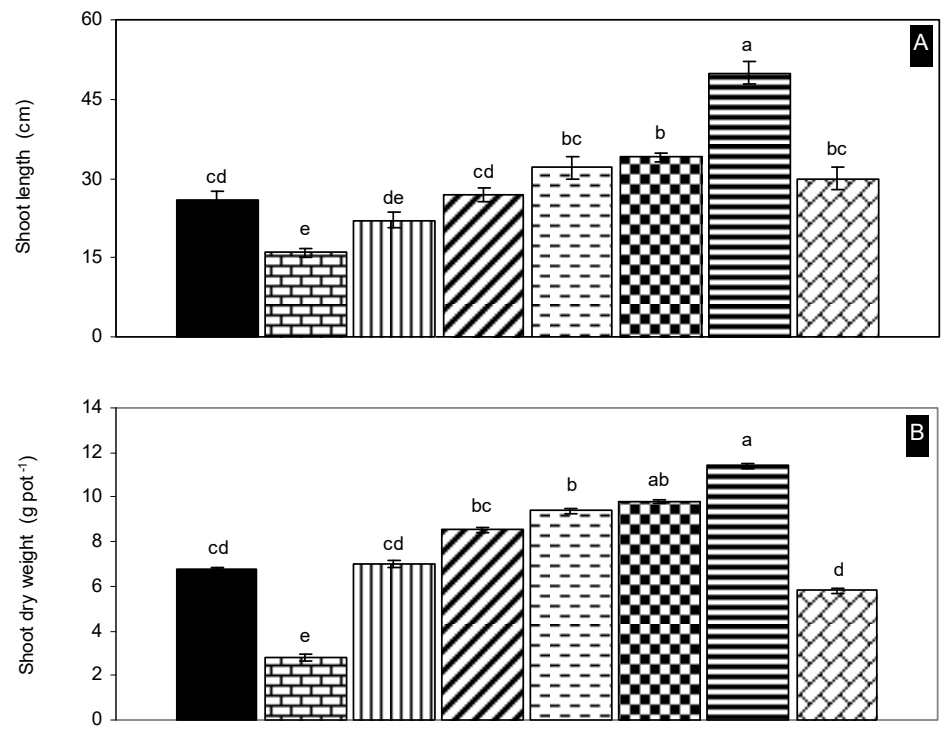

Vertical bars show standard errors of means of three replicates. Values with different letters at their top show significant difference $(\mathrm{P} \leq 0.05)$ as determined by Tukey's HSD Test.

Figure 2 - Effect of Macrophomina phaseolina (MP) and soil amendment with dry biomass of Sonchus oleraceous (DBS) on shoot growth of urdbean.
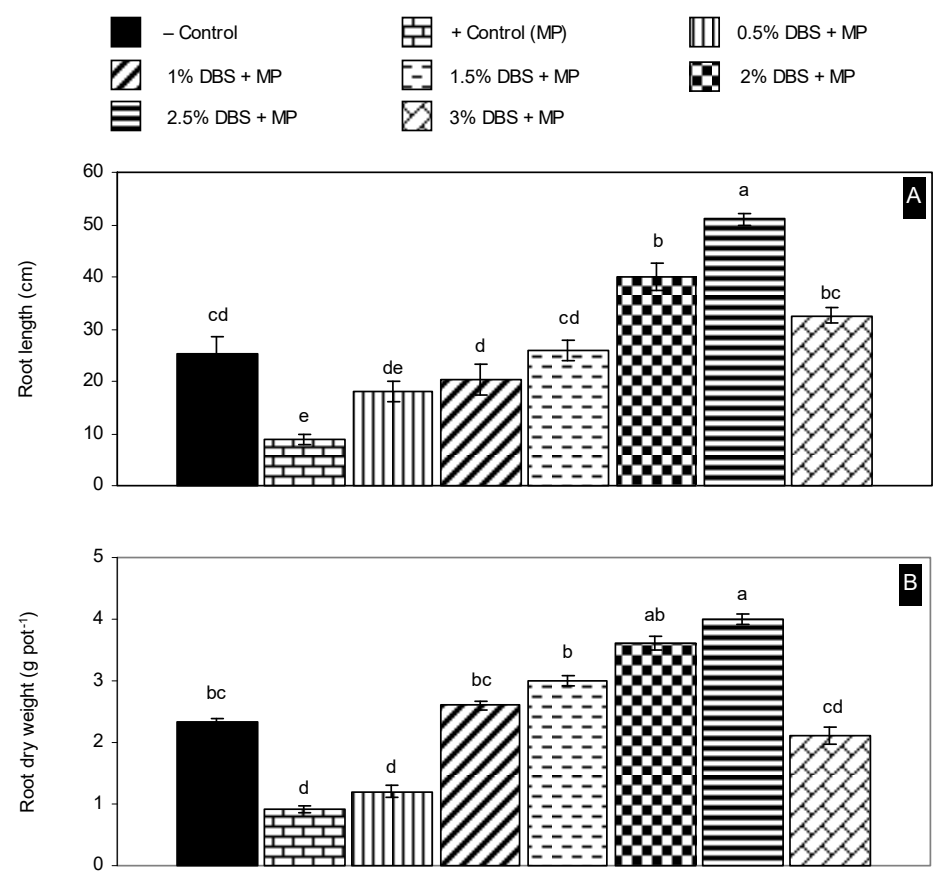

Vertical bars show standard errors of means of three replicates. Values with different letters at their top show significant difference (P $\leq 0.05$ ) as determined by Tukey's HSD Test.

Figure 3 - Effect of Macrophomina phaseolina (MP) and soil amendment with dry biomass of Sonchus oleraceous (DBS) on root growth in urdbean. 


\section{Effect of soil amendment on yield}

M. phaseolina inoculation caused 37\%, 66\% and 47\% decrease in pod length, pod dry weight, and pod number, respectively, over negative control. Different doses of soil amendment significantly improved all these parameters over positive control. The greatest length, number and dry weight of pods i.e. $5.2 \mathrm{~cm}, 29$ and $11.5 \mathrm{~g}$ per pot were recorded in $2.5 \%$ amendment of S. oleraceous. An increase of $785 \%$ in pod dry weight was recorded due to $2.5 \%$ residue incorporation of $S$. oleraceous over positive control (Figure 4).
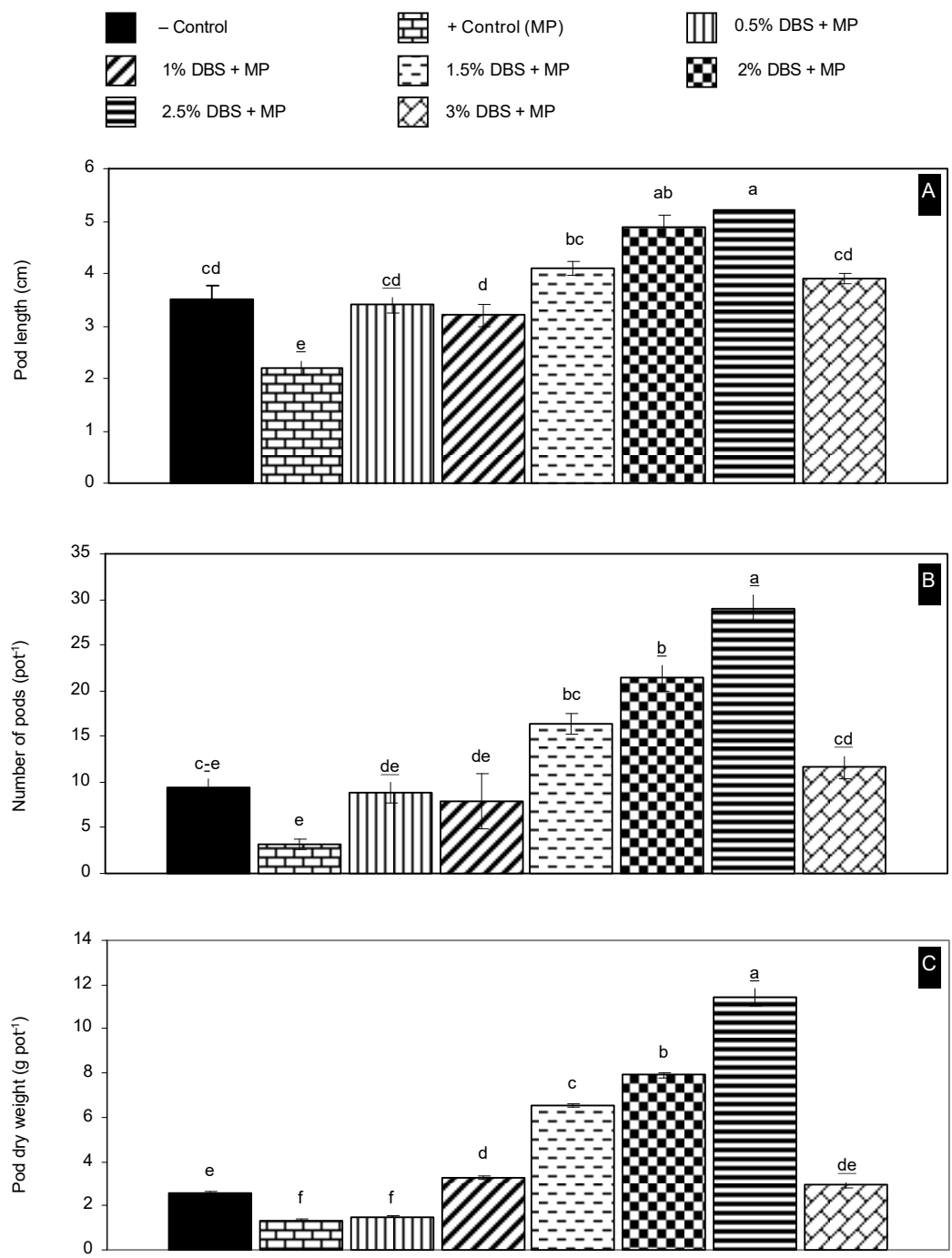

Vertical bars show standard errors of means of three replicates. Values with different letters at their top show significant difference (P $\leq 0.05)$ as determined by Tukey's HSD Test.

Figure 4 - Effect of Macrophomina phaseolina (MP) and soil amendment with dry biomass of Sonchus oleraceous (DBS) on pod yield in urdbean.

There was a significant reduction of $39 \%, 59 \%$ and $91 \%$ weight of 100 grains, number of grains per pod and grain yield per pot due to M. phaseolina inoculation as compared to uninoculated negative control. All the yield related parameters were gradually increased by increasing the dose of dry materials of $S$. oleraceous as soil amendment up to $2.5 \%$ and a decline thereafter. A raise of $7400 \%$ in grain yield was recorded owing to $2.5 \%$ dose over positive control followed by $4900 \%$ increase due to $2.0 \%$ dose. Grain yield in 3\% amendment treatment was insignificantly different over negative as well as positive control treatments (Figure 5). 


\begin{tabular}{|c|c|c|c|}
\hline 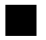 & - Control & 臣＋Control (MP) & $0.5 \% \mathrm{DBS}+\mathrm{MP}$ \\
\hline$Q$ & $1 \% \mathrm{DBS}+\mathrm{MP}$ & $--1.5 \% \mathrm{DBS}+\mathrm{MP}$ & $2 \% \mathrm{DBS}+\mathrm{MP}$ \\
\hline 国 & $2.5 \% \mathrm{DBS}+\mathrm{MP}$ & 3 3 DBS + MP & \\
\hline
\end{tabular}
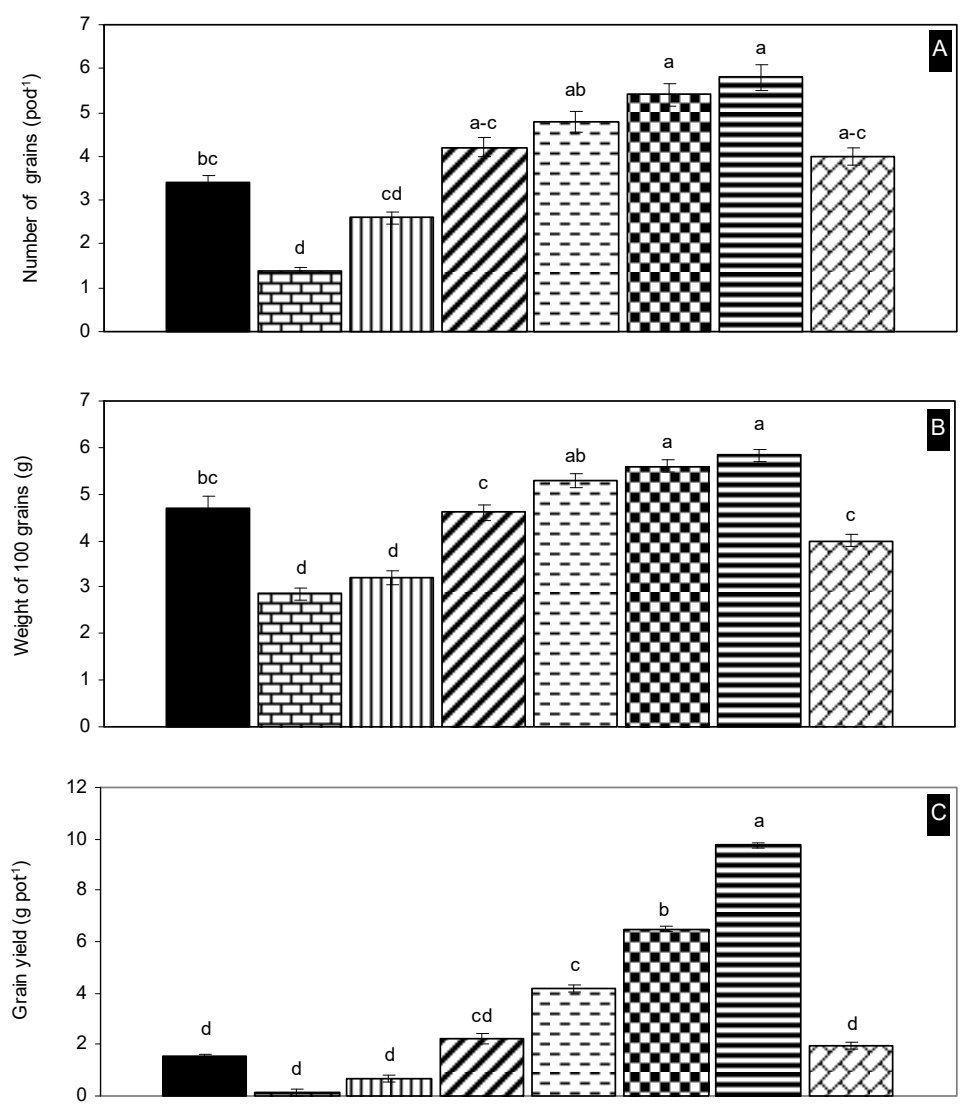

Vertical bars show standard errors of means of three replicates. Values with different letters at their top show significant difference $(\mathrm{P} \leq 0.05)$ as determined by Tukey's HSD Test.

Figure 5 - Effect of Macrophomina phaseolina (MP) and soil amendment with dry biomass of Sonchus oleraceous (DBS) on grain yield in urdbean.

\section{Effect of soil amendment on harvest index}

M. phaseolina inoculation inoculation caused a significant reduction of $81 \%$ in harvest index. This parameter was significantly increased over positive control due to application of different doses of soil amendment up to $2.5 \%$. The highest harvest index i.e. $23.5 \%$ was recorded due to $2.5 \%$ followed by $20.5 \%$ and $17 \%$ because of $2.0 \%$ and $1.5 \%$ doses, respectively, as compared to the lowest one $(2.58 \%)$ recorded in positive control (Figure 6).

\section{Effect of soil amendment on enzymatic activities}

Peroxidase (POX) activity differed significantly among the treatments. The highest POX activity was found in plants of positive control followed by $0.5 \%$ dose. The lowest POX activity (6.32 $\mathrm{U} \mathrm{min}^{-1} \mathrm{mg}^{-1}$ of protein) was noted in plants of negative control. Generally, POX activity was decreased with increase in amount of $S$. oleraceous biomass as soil amendment (Figure 7A). Phenylalanine ammonia lyase (PAL) activity showed a marked variation among the treatments. The highest PAL activity was recorded in plants of positive control followed by in plants of $0.5 \%$ and $1.0 \%$ doses, respectively. The lowest PAL activity was shown by plants of $3.0 \%$ amendment. This activity was also considerably low in plants of negative control (Figure 7B). Increased activities of PAL and POX lead to enhanced production of lignin and secondary metabolites 


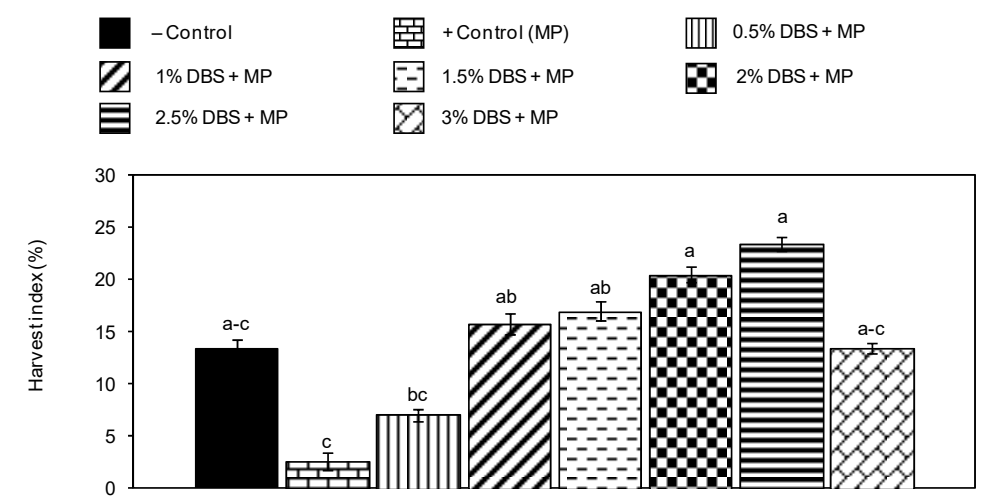

Vertical bars show standard errors of means of three replicates. Values with different letters at their top show significant difference (P $\leq 0.05)$ as determined by Tukey's HSD Test.

Figure 6 - Effect of Macrophomina phaseolina (MP) and soil amendment with dry biomass of Sonchus oleraceous (DBS) on harvest index in urdbean plants.

\begin{tabular}{|c|c|c|}
\hline - Control & 臣詈 + Control (MP) & 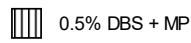 \\
\hline $1 \% \mathrm{DBS}+\mathrm{MP}$ & $1.5 \% \mathrm{DBS}+\mathrm{MP}$ & W2\% DBS +MP \\
\hline $2.5 \% \mathrm{DBS}+\mathrm{MP}$ & $3 \% \mathrm{DBS}+\mathrm{MP}$ & \\
\hline
\end{tabular}
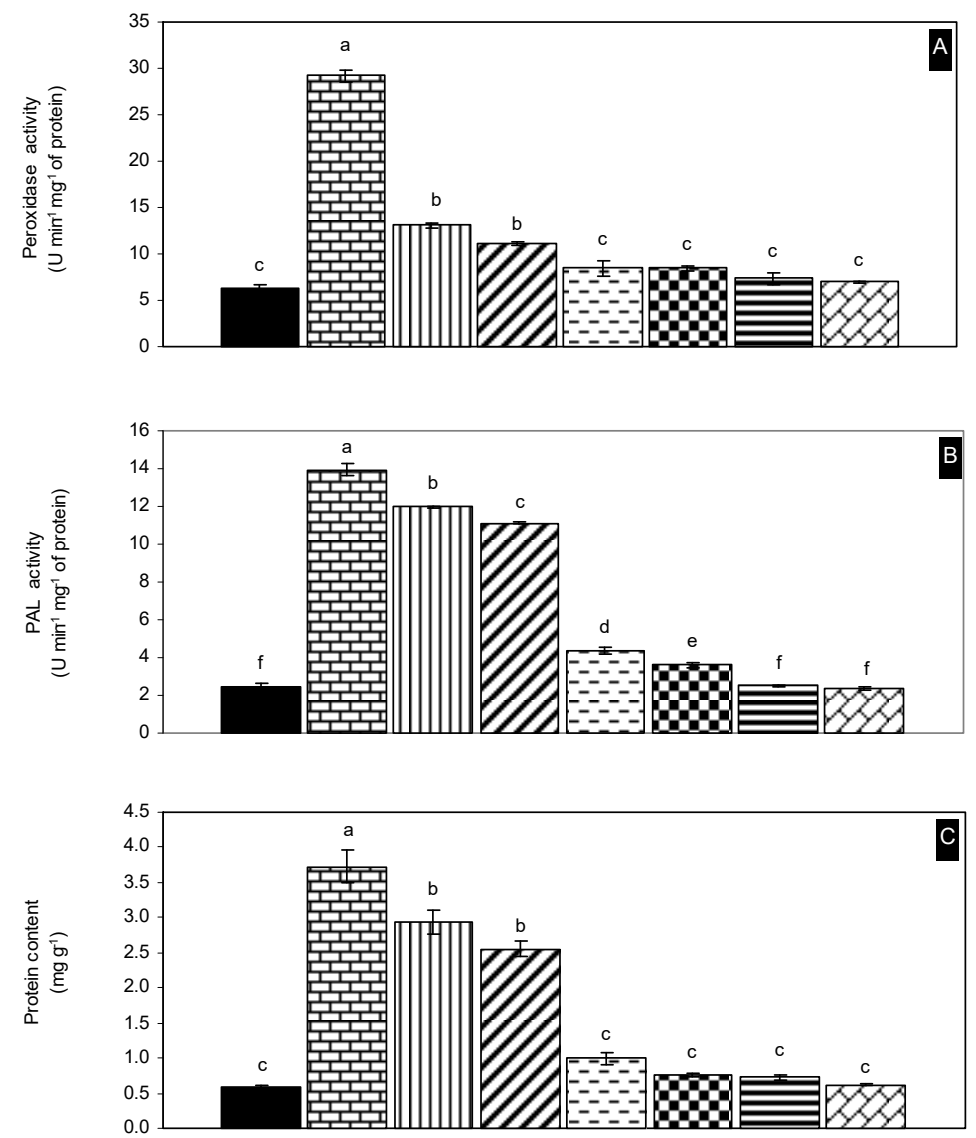

Vertical bars show standard errors of means of three replicates. Values with different letters at their top show significant difference (P $\leq 0.05)$ as determined by Tukey's HSD Test.

Figure 7 - Effect of Macrophomina phaseolina (MP) and soil amendment with dry biomass of Sonchus oleraceous (DBS) on peroxidase (POX) and phenyl alanine ammonia lyase (PAL) activities of urdbean plants. 
including phenolic and flavonoids, which possess antioxidant and antimicrobial potential (Mahmoudi et al., 2016). However, the way these genes encoding POX and PAL corresponding enzymes react in terms of speed after pathogen infection is different, depending on the nature of plant pathogen interactions (Daudi et al., 2012). Increased activities of oxidizing enzymes like POX and PAL in urdbean due to $M$. phaseolina indicated response against disease stress (Khan et al., 2018). Soil amendment with $S$. oleraceous may provide protection against pathogen by antagonizing pathogen and normalizing its effect on plant that would plant face otherwise as revealed by less enzymes activities (Shoaib et al., 2018).

The results of present study conclude that charcoal rot disease of urdbean can successfully be managed by soil amendment with residues of $S$. oleraceous using a $2.5 \%$ dose on w/w ratio. Field study is recommended to verify the results of present pot trial.

\section{REFERENCES}

Al-Hussaini R, Mahasneh AM. Antibacterial and antifungal activity of ethanol extract of different parts of medicinal plants in Jordan. Jordan J Pharmaceut Sci. 2011;4:57-69.

Anonymous. 2018. Pakistan Economic Survey 2017-18. Economic Adviser's Wing, Finance Division, Government of Pakistan, Islamabad.

Baird RE, Watson CE, Scruggs M. Relative longevity of Macrophomina phaseolina and associated mycobiota on residual soybean roots in soil. Plant Dis. 2003;87:563-66.

Banaras S, Javaid A, Iqbal SM. Use of methanolic extracts of an asteraceous weed Eclipta alba for control of Macrophomina phaseolina. Pak J Weed Sci Res. 2015;21:101-110.

Banaras S, Javaid A, Shoaib A, Ahmed E. Antifungal activity of Cirsium arvense extracts against a phytopathogenic fungus Macrophomina phaseolina. Planta Daninha. 2017;35:e017162738.

Bonanomi G, Antignani V, Capodilupo M, Scala F. Identifying the characteristics of organic soil amendments that suppress soilborne plant diseases. Soil Biol Biochem. 2010;42:136-44.

Cambie RC, Ferguson LR. Potential functional foods in the traditional Maori diet. Mutat Res. 2003;523:109-17.

Carvalho RS, Carollo CA, de Magalhaes JC. Antibacterial and antifungal activities of phenolic compound-enriched ethyl acetate fraction from Cochlospermum regium (mart. Et. Schr.) Pilger roots: Mechanisms of action and synergism with tannin and gallic acid. South Afr J Bot. 2018;114:181-7.

Chamorro M, Seijo TE, Noling JC, Santos BDL, Peres NA. Efficacy of fumigant treatments and inoculum placement on control of Macrophomina phaseolina in strawberry beds. Crop Prot. 2016;90:163-9.

Christopher M, Macdonald B, Yeates S, Ziegler D. Seymour N. Wild bradyrhizobia that occur in the Burdekin region of Queensland are as effective as commercial inoculum for mungbean [Vigna radiata (L.)] and black gram (Vigna mungo L.) in fixing nitrogen and dry matter production. Appl Soil Ecol. 2018;124:88-94.

Daudi A, Cheng Z, O’Brien JA, Mammarella N, Khan S, Ausubel FM, Bolwell GP. The apoplastic oxidative burst peroxidase in Arabidopsis is a major component of pattern-triggered immunity. Plant Cell. 2012;24:275-87.

Dey A, De PS, Gangopadhyay PK. Black gram (Vigna Mungo L.) foliage supplementation to crossbred cows: effects on feed intake, nutrient digestibility and milk production. Asian-Australas J Anim Sci. 2017;30:187-91.

Dickerson DP, Pascholati SF, Hagerman AE, Butler LG, Nicholson RL. Phenylalanine ammonia-lyase and hydroxycinnamate: CoA ligase in maize mesocotyls inoculated with Helminthosporium maydis or Helminthosporium carbonum. Physiol Plant Pathol. $1984 ; 25: 111-123$.

Iqbal SM, Ghafoor A, Arshad M, Bashir M. Screening of urdbean (Vigna mungo) germplasm for resistance to charcoal rot disease. Plant Pathol J. 2003;2:107-110.

Javaid A, Amin M. Antifungal activity of methanol and $n$-hexane extracts of three Chenopodium species against Macrophomina phaseolina. Nat Prod Res. 2009;23:1120-7. 
Javaid A, Saddique A. Management of Macrophomina root rot of mungbean using dry leaves manure of Datura metel as soil amendment. Span J Agric Res. 2011;9:901-5.

Javaid A., Naqvi S.F., Shoaib A., Iqbal S.M. Management of Macrophomina phaseolina by extracts of an allelopathic grass Imperata cylindrica. Pak J Agric Sci. 2015;52:37-41.

Javaid A, Qudsia H, Shoaib A. Bioassays guided fractionation of Senna occidentalis for identification of natural antifungal constituents against Macrophomina phaseolina. Planta Daninha. 2017a;35:e017163483.

Javaid A, Afzal L, Shoaib A. Biological control of charcoal rot of mungbean by Trichoderma harzianum and shoot dry biomass of Sisymbrium irio. Planta Daninha. 2017;35:e017165756.

Kaur S, Dhillon GS, Brar SK, Vallad GE, Chand R, Chauhan VB. Emerging phytopathogen Macrophomina phaseolina: biology, economic importance and current diagnostic trends. Crit Rev Microbiol. 2012;38:136-51.

Khan KA, Shoaib A, Awan ZA, Basit A, Hussain M. Macrophomina phaseolina alters the biochemical pathway in Vigna radiata chastened by $\mathrm{Zn}^{2+}$ and FYM to improve plant growth. J Plant Interact. 2018;13:131-40.

Kumar KB, Khan PA. Peroxidase in excised ragi (Eleusine coracana cv. PR 202) leaves during senescence. Int J Exp Bot. 1982;20:412-416.

Lorenzetti E, Stangarlin JR, Kuhn OJ. Antifungal activity of rosemary extract on Macrophomina phaseolina and charcoal rot control in soybean. J Plant Pathol. 2017;99:783-86.

Mahmoudi S, Khali M, Benkhaled A, Benamirouche K, Baiti I. Phenolic and flavonoid contents, antioxidant and antimicrobial activities of leaf extracts from ten Algerian Ficus carica L. varieties. Asian-Pacific J Trop. Biomed. 2016;6:239-45.

Mouokeu RS, Ngane RAN, Njateng GSS, Kamtchueng MO, Kuiate JR, Antifungal and antioxidant activity of Crassocephalum bauchiense Milne-Redh ethyl acetate extract and fractions (Asteraceae). BMC Res Notes. 2014;7:244.

Munir M, Shoaib A, Javaid A, Arshad Z, Rafiq M. Anti-mycotic potential of Trichoderma spp. and leaf biomass of Azadaricta indica against the charcoal rot pathogen Macrophomina phaseolina (Tassi) Goid in cowpea. Egypt J Biol Pest Control. 2018;28:26.

Nino J, Narváez MD, Mosquera OM, Corre YM. Antibacterial, antifungal and cytotoxic activities of eight Asteraceae and two Rubiaceae plants from Colombian biodiversity Brazilian. J. Microbiol. 2006;37:115-9.

Qasem JR, Aau-Blan HA. Fungicidal activity of some common weed extracts against different plant pathogenic fungi. J. Phytopathol. 1996;144:157-61.

Rajaguru ASB, Ravindran V. 1985. Metabolisable energy values for growing chicks of some feedstuffs from Sri Lanka. J Sci Food Agric. 1985;36:1057-64.

Shafique S, Khan MR, Nisar M, Rehman SU. Investigation of genetic diversity in black gram [Vigna mungo (L.) Hepper]. Pak J Bot. 2011;43:1223-32.

Shoaib A, Munir M, Javaid A, Awan ZA, Rafiq M. Anti-mycotic potential of Trichoderma spp. and leaf biomass of Azadirachta indica against the charcoal rot pathogen, Macrophomina phaseolina (Tassi) Goid in cowpea. Egypt J Biol Pest Control. 2018;28:26.

Singh S. Phytochemical investigation of Sonchus oleraceous leaves and Citrullus colocynth root. J. Herbal Med. Toxicol. 2010;4:159-62.

Vishalakshi B, Umakanth B, Shanbhag AP, Ghatak A, Sathyanarayanan N, Madhav MS, et al. RAPD assisted selection of black gram [Vigna mungo (L.) Hepper] towards the development of multiple disease resistant germplasm. 3 Biotech. 2017; 7:1.

Vyas D, Joshi A, Rajamani G, Jain D. Assessment of genetic diversity in black gram [Vigna mungo (L.) Hepper] genotypes based on ISSR. Leg Res. 2018;41:175-81.

Waheed N, Jabeen K, Iqbal S, Javaid A. Biopesticidal activity of Calotropis procera L. against Macrophomina phaseolina. Afr. J. Trad. Complement. Altern. Med. 2016;13:163-7. 